\title{
Is oral hygiene performed by caregivers of children and adolescents with
}

\section{cerebral palsy effective?}

\author{
A realização da higiene oral realizada por cuidadores de crianças e adolescentes com paralisia \\ cerebral é eficaz? \\ ¿Es eficaz la higiene bucal que realizan los cuidadores de niños y adolescentes con parálisis \\ cerebral?
}

Received: 10/30/2021 | Reviewed: 11/09/2021 | Accept: 11/15/2021| Published: 11/16/2021

\author{
Valéria Marques Bordallo Pacheco \\ ORCID: https://orcid.org/0000-0002-3610-2784 \\ Universidade Cruzeiro do Sul, Brasil \\ E-mail: leriabordallo@gmail.com \\ Ana Cristina Fernandes Maria Ferreira \\ ORCID: https://orcid.org/0000-0001-5154-7530 \\ Universidade Cruzeiro do Sul, Brasil \\ E-mail: anacristina.ferreira@gmail.com \\ Carolina de Andrade Ferreira \\ ORCID: https://orcid.org/0000-0002-0051-9721 \\ Universidade Cruzeiro do Sul, Brasil \\ E-mail: andradecarol96@hotmail.com \\ Vanessa Lira Siqueira \\ ORCID: https://orcid.org/0000-0001-9521-3110 \\ Universidade Cruzeiro do Sul, Brasil \\ E-mail: vanricsiquerira@gmail.com \\ Maria Teresa Botti Rodrigues Santos \\ ORCID: https://orcid.org/0000-0002-1276-8012 \\ Universidade Cruzeiro do Sul, Brasil \\ E-mail: maria.botti@cruzeirodosul.edu.br
}

\begin{abstract}
Objective: To evaluate the effectiveness of oral hygiene performed by caregivers of children and adolescents with cerebral palsy (CP) during the moments before and after three months of oral health instructions. Methods: In a longitudinal study, 102 participants were joined in two groups: G1 $(n=51)$ composed of children and adolescents (C/A) with CP and G2 (n=51), composed of their caregivers. Sociodemographic and oral hygiene habits were collected and evaluated using the Visible Plaque Index (VPI) and Gingival Bleeding Index (GBI), before and after oral hygiene orientation. The Qui-Squared, ANOVA 1, and tStudent tests were applied. P $<0,05$. Results: The C/A group with pattern clinical $\mathrm{CP}$ tetraparesis, diparesis and hemiparesis were homogeneous in terms of gender $(\mathrm{P}=$ $0,07)$, however differed in age $(\mathrm{P}<0,05)$, the youngest being diparetic. No difference was observed when comparing VPI and GBI before and after instructions in oral health for the three clinical types $(\mathrm{P}>0,05)$. However, a reduction in the VPI and GBI indexes $(\mathrm{P}<0,05)$ before and after, in each of the three clinical patterns. Most of the caregivers were female, married, with a high school degree, and they performed oral hygiene three times per day. The caregivers presented significant drops in VPI and GBI after receiving oral hygiene instructions. ( $\mathrm{P}<0,05)$. Conclusion: Oral hygiene instruction is fundamental for the caregivers of children and adolescents with cerebral palsy since it is an effective form of controlling health problems.
\end{abstract}

Keywords: Oral health; Cerebral palsy; Caregivers; Oral hygiene.

\section{Resumo}

Objetivo: Avaliar a efetividade da higiene oral realizada por cuidadores de crianças e adolescentes com paralisia cerebral (PC) antes e após três meses de instruções em saúde bucal. Métodos: Em estudo longitudinal prospectivo, 102 participantes foram reunidos em dois grupos: G1 ( $\mathrm{n}=51)$ crianças e adolescentes (C/A) com PC; G2 ( $\mathrm{n}=51)$ seus cuidadores. Foram coletados dados sociodemográficos e hábitos de higiene bucal, avaliados pelos índices de placa visível (IPV) e de sangramento gengival (ISG), antes e após orientações de higiene oral. Foram empregados os testes do Qui-quadrado, teste ANOVA 1 critério e Teste t Student. P < 0,05. Resultados: Os grupos das C/A com PC padrão clínico tetraparesia, diparesia e hemiparesia eram homogêneos quanto ao sexo $(P=0,07)$, porém diferiram quanto à idade $(P<0,05)$, sendo os diparéticos mais jovens. Não foi observada diferença na comparação do IPV e ISG antes e 
após instruções em saúde bucal para os três tipos clínicos ( $\mathrm{P}>0,05)$. Entretanto, pode-se observar redução nos índices IPV e ISG $(\mathrm{P}<0,05)$ antes e após, nos três padrões clínicos. A maioria dos cuidadores era do sexo feminino, casada, ensino médio completo e realizavam higiene bucal três vezes ao dia. Os cuidadores apresentaram redução significante do IPV e ISG após instruções de higiene oral $(\mathrm{P}<0,05)$. Conclusão: É fundamental a instrução de higiene oral aos cuidadores de crianças e adolescentes com paralisia cerebral, pois esta é uma forma eficaz para o controle dos agravos a saúde.

Palavras-chave: Paralisia cerebral; Higiene bucal; Cuidadores; Saúde bucal.

\section{Resumen}

Objetivo: Evaluar la efectividad de la higiene bucal que realizan los cuidadores de niños y adolescentes con parálisis cerebral (PC) antes y después de tres meses de instrucciones en salud bucal. Métodos: En un estudio longitudinal prospectivo, 102 participantes fueron divididos en dos grupos: G1 $(n=51)$ niños y adolescentes $(\mathrm{N} / \mathrm{A})$ con PC; G2 $(\mathrm{n}=51)$ sus cuidadores. Se recogieron datos sociodemográficos y hábitos de higiene bucal, evaluados mediante índices de placa visible (IPV) y sangrado gingival (ISG), antes y después de las pautas de higiene bucal. Se utilizó la prueba de Chi-cuadrado, la prueba de criterio ANOVA 1 y la prueba de la t de Student. P <0,05. Resultados: Los grupos de N / A con patrón clínico PC tetraparesia, diparesia y hemiparesia fueron homogéneos en cuanto al sexo $(\mathrm{P}=$ $0,07)$, pero difirieron en cuanto a la edad $(\mathrm{P}<0,05)$, siendo el diparesia más joven. No se observaron diferencias al comparar IPV e ISG antes y después de las instrucciones en salud bucal para los tres tipos clínicos $(\mathrm{P}>0.05)$. Sin embargo, se puede observar una reducción en los índices IPV e ISG (P <0.05) antes y después, en los tres patrones clínicos. Los cuidadores mostraron una reducción significativa en IPV e ISG después de las instrucciones de higiene bucal ( $\mathrm{P}<0.05)$. Conclusión: La instrucción en higiene bucal para los cuidadores de niños y adolescentes con parálisis cerebral es fundamental, ya que es una forma eficaz de controlar los problemas de salud.

Palabras clave: Parálisis cerebral; Higiene bucal; Cuidadores; Salud bucal.

\section{Introduction}

Dentistry currently has become more accessible to a significant percentage of the Brazilian population. However, when it comes to awareness of oral hygiene, access to information is not yet so widespread, causing an impact on the individual's quality of life (Naseem et al., 2016). We know that oral health can contribute to health improvement generally, self-esteem and social integration (Grecu et al., 2019).

When it comes to individuals with physical handicaps, the caregiver has a fundamental role, since the majority can be directly dependent on the caregiver for their oral care and health, who therefore assume an essential role in the lives of these people (Petersen, 2003). For this reason, it is important for these caregivers to have knowledge and awareness of the preventive practices of ideal oral health maintenance for these individuals under their care (DeMattei, Allen, \& Goss, 2012; Petersen, 2003).

Recent studies have shown that the periodontal illness is one of the most prevalent oral illnesses, especially in populations with worse socioeconomic indicators, such as income and education, a condition that is also confirmed in Brazil (Chałas et al., 2015; Chi, 2018). It results from the inflammatory pathological state initiated in response to the accumulation of biofilm, considered the primary etiological factor of the disease (Pini, Fröhlich, \& Rigo, 2016). Periodontitis is characterized by the loss of progressive insertion, including destruction of periodontal ligament and of the alveolar bone support with consequent formation of a periodontal pocket, which occurs due to microbial accumulation modulated by a series of environmental, local and systemic factors (Kumar et al., 2003). Gingivitis can be evaluated from the Gingival Bleeding Index (GBI) post-probing and biofilm evidencing, while measurement of the depth of periodontal pockets has been used as an indicator of periodontitis (Chi, 2018; Dos Santos \& Nogueira, 2005; Koman, Smith, \& Shilt, 2004; Longo \& Hankins, 2009;

Oskoui, Coutinho, Dykeman, Jetté, \& Pringsheim, 2013; Rosenbaum et al., 2007).

Cerebral Palsy (CP) includes a group of developmental disorders related to movement and posture, causing limitations to daily activities (Longo \& Hankins, 2009; Oskoui et al., 2013). It is the main factor of physical disability in childhood (Santos, Ferreira, Mendes, \& de Oliveira Guaré, 2014). 
Motor damage is the fundamental alteration, however comorbidities such as neurological and orthopedic alterations, behavioral disturbances and proprioception and musculoskeletal impairment are observed (Cardoso et al., 2014; DU, McGrath, Yiu, \& King, 2010). Clinical CP patterns of the spastic type include tetraparesis, diparesis and hemiparesis (Vitrikas, Dalton, $\&$ Breish, 2020). The presence of primitive oral reflexes such as the bite, contributes negatively to the execution of oral hygiene and use of dental floss (Rodrigues dos Santos, Masiero, Novo, \& Simionato, 2003). The continuous use of antiepileptic medication, reduction of salivary flow and the buffering capacity of saliva, associated with higher values of salivary osmolarity, increase the risk of caries and periodontal diseases in these individuals (Highfield, 2009; Rodrigues dos Santos et al., 2003).

The accumulation of biofilm is a determining factor in the development of caries and periodontal diseases. And knowing that children and adolescents with $\mathrm{CP}$ have difficulty in performing oral hygiene, this group is considered vulnerable to oral diseases (Aburahma, Mhanna, Al-Mousa, Al-Nusair, \& Al Habashneh, 2021).

Knowing the importance of caregivers in the trajectory of these children and adolescents to adulthood, it is necessary for the dental professional to exercise the role of educator in oral health through instruction to caregivers of these people. Therefore, the aim of this study was to evaluate the effectiveness of oral hygiene performed by caregivers of children and adolescents with $\mathrm{CP}$ in the moments before and after three months of instructions in oral health. The study hypothesis was that children and adolescents with $\mathrm{CP}$ need support from their caregivers to perform oral hygiene to reduce the periodontal inflammatory process.

\section{Methodology}

\section{Ethical Aspects}

This study was approved by the Ethics in Research Committee at Universidade Cruzeiro do Sul - Platform Brazil, São Paulo, SP, number 3.272.539 according to resolution 466/2012 of the Ministry of Health. The Informed Consent Form was obtained from the caregivers of each participant, after they received information about the study.

\section{Study Design}

A prospective longitudinal study was carried out with children and adolescents diagnosed with CP who received dental treatment at the clinic of the Dentistry for Special Patients course of the Dentistry course at Cruzeiro do Sul University, São Paulo, Brazil at the time of data collection.

\section{Participants}

Sixty children and adolescents with CP and their caregivers were invited to participate in this study. Data was collected between April and December 2019. Data collection was carried out after the legal guardian and the minor signed the Informed Consent Form after they were informed about the study. Children and adolescents with a medical diagnosis of $\mathrm{CP}$, aged between 3 and 15 years, and both genders were included. Non-collaborating children and adolescents and those whose caregivers were not available to accompany the participant to all consultations during the 3 months of the study were excluded.

Data related to sex, age and CP clinical pattern (tetraparesis, diparesis, hemiparesis) were collected from the participants' medical records.

Initially, caregivers received instructions on how to perform the oral hygiene of the children after biofilm detection, in order to facilitate the visualization of the places that required greater attention during the performance of oral hygiene. This method of health education is considered motivational. Next, the caregivers were trained in skills and proposed adaptations of 
brushes and mouth openers, to reduce the risk of bite caused by the bite reflex and/or behavioral change, providing access to the entire oral cavity. Use of dental floss with thickened brush stems and handles was recommended.

Clinical evaluations were performed by a single calibrated examiner. These included the Visible Plaque Index (VPI) (O'Leary, Drake, \& Naylor, 1972) and the Gingival Bleeding Index (GBI) (Chapple et al., 2018), using a flat mouth mirror, North Carolina Universal Periodontal Probe 15mm and Eviplac Eviplac Vial - Biodynamic 10ml.

After three months, reassessments were carried out to verify the effectiveness of the oral health instructions received. The findings in both moments were recorded in each participant's individual form.

Visible Plaque Index (O'Leary et al., 1972).

The O'Leary plaque index (O'Leary et al., 1972) consists of the plaque control record (Plaque Control Record) expressed as a percentage, based on the presence of plaque on the mesial, distal, buccal and lingual dental surfaces /palatinate. This index was performed with the aid of a microbrush, depositing the evidencing liquid on the dental surface. The calculation was performed by dividing the number of surfaces with plaque by the total number of surfaces examined. An index of up to $20 \%$ of surfaces with plaque is considered acceptable.

Gingival bleeding index (Chapple et al., 2018).

The first clinical sign of the presence of changes in the physiology of the gingival tissue is bleeding, whether caused by probing and/or spontaneous. Bleeding is classified within risk factors, as an indicator of the presence of the disease, not its severity (Chapple et al., 2018). Among the various parameters used to assess the presence or absence of the disease and its response to some type of therapy, is bleeding by probing, used in several studies(Chapple et al., 2018).

The evaluation of the GBI was performed using a $15 \mathrm{~mm}$ North Carolina universal periodontal probe that was gently passed over the gingival margin of all teeth, at an approximate position of $45^{\circ}-60^{\circ}$ in relation to the long axis of the tooth, having as reference unit the distobuccal papilla, the buccal margin, the mesiobuccal papilla and the lingual/palatal margin. Partially erupted teeth and residual roots were excluded without replacement. The index was calculated by the percentage of the sum of the individual values of each tooth, divided by the number of faces examined. After the initial assessment, the participants and their caregivers received individual dental treatment, that is, according to the needs of each one.

\section{Statistical Analysis}

Chi-square tests were used to compare categorical variables, 1-way ANOVA test for continuous variables and paired Student $\mathrm{t}$ test to compare values before and after. The significance value was set at $\mathrm{P}<0.05$.

\section{Results}

The final sample consisted of 102 people divided into 2 groups: Group 1 (G1) composed of 51 children and adolescents with CP, and Group 2 (G2) of 51 caregivers of children and adolescents with CP. Nine people with CP were excluded due to uncooperative behavior during the clinical examination.

Children and adolescents with $\mathrm{CP}$ were divided into 3 groups, according to the clinical pattern of tetraparesis, diparesis or hemiparesis (Table 1). 
Table 1. Description of subjects with cerebral palsy according to clinical pattern, gender, age, Visible Plaque Index and Gingival Bleeding Index.

\begin{tabular}{|c|c|c|c|c|c|}
\hline $\begin{array}{c}\text { Variables } \\
(\text { mean } \pm \text { SD })\end{array}$ & $\begin{array}{c}\text { Tetraparesis } \\
\text { G1 }(\mathbf{n}=\mathbf{3 1})\end{array}$ & $\begin{array}{c}\text { Diparesis } \\
\text { G2 }(n=16)\end{array}$ & $\begin{array}{c}\text { Hemiparesis } \\
\text { G3 }(n=4)\end{array}$ & $\begin{array}{c}\text { Total } \\
(n=51)\end{array}$ & $\begin{array}{c}\mathbf{P} \\
\text { Value }\end{array}$ \\
\hline \multicolumn{6}{|l|}{ Gender } \\
\hline Female & $14(45,2 \%)$ & $3(18,8 \%)$ & $3(75 \%)$ & $20(39,2 \%)$ & 0,07 \\
\hline Male & $17(54,8 \%)$ & $13(81,2 \%)$ & $1(25 \%)$ & $31(60,8 \%)$ & \\
\hline Age & $10,3 \pm 5,2 \mathrm{~A}$ & $5,8 \pm 3,9 \mathrm{~B}$ & $13,5 \pm 7,3 \mathrm{~A}$ & $9,1 \pm 5,7$ & $<0,05^{*}$ \\
\hline VPI (initial) & $30,4 \pm 14,2 \mathrm{Aa}$ & $28,2 \pm 5,7 \mathrm{Aa}$ & $40,3 \pm 20,2 \mathrm{Aa}$ & $24,1 \pm 14,6$ & 0,0889 \\
\hline VPI (final) & $\begin{array}{c}19,1 \pm 17,1 \mathrm{Ab} \\
(0,015)\end{array}$ & $\begin{array}{c}18,8 \pm 15,6 \mathrm{Ab} \\
(0,059)\end{array}$ & $\begin{array}{c}14,0 \pm 10,14 \mathrm{Ab} \\
(0,0027)\end{array}$ & $19,1 \pm 19,1$ & 0,6727 \\
\hline GBI (initial) & $19,6 \pm 19,1 \mathrm{Aa}$ & $14,1 \pm 13.0 \mathrm{Aa}$ & $26,25 \pm 27,6 \mathrm{Aa}$ & $21,0 \pm 18,7$ & 0,5340 \\
\hline GBI (final) & $\begin{array}{c}8,07 \pm 14,10 \mathrm{Ab} \\
(0,0001)\end{array}$ & $\begin{array}{c}7,7 \pm 13,2 \mathrm{Ab} \\
(0,016)\end{array}$ & $\begin{array}{c}8,50 \pm 10,63 \mathrm{Ab} \\
(0,069)\end{array}$ & $16,6 \pm 20,1$ & 0,9955 \\
\hline
\end{tabular}

Mean values \pm standard deviation or percentage (\%); P values with significance* fixed at $\mathrm{P}<0.05$. Chi-square test and ANOVA 1 criterion. Different letters show a statistically significant difference $(\mathrm{P}<0.05)$, Uppercase letters compare values horizontally and lowercase letters vertically. Abbreviations: VPI: Visible Plaque Index, GBI: Gingival Bleeding Index. Source: Authors.

The groups were homogeneous in terms of sex $(\mathrm{P}=0.07)$ but differed in terms of age $(\mathrm{P}<0.05)$, with children and adolescents with clinical pattern diparesis being significantly younger.

Comparison of the PVI and the initial and final GBI between the clinical patterns of children and adolescents with CP showed no significant difference $(\mathrm{P}>0.05)$. However, it can be observed that when comparing the initial and final values within each clinical pattern group, there was a significant reduction $(\mathrm{P}<0.05)$ for PVI and GBI (Table 1).

In Table 2, data referring to caregivers of children and adolescents with $\mathrm{CP}$ is presented. It can be observed that most caregivers were female, married, with high school education, and performed oral hygiene 3 times a day. Most did not use dental floss. 
Table 2. Sociodemographic data and oral hygiene habits collected from caregivers of individuals with cerebral palsy in the initial assessment.

\begin{tabular}{lc}
\hline Variables & $\begin{array}{c}\text { Caregivers } \\
(\mathbf{n = 5 1})\end{array}$ \\
\hline Gender & $48(94,1 \%)$ \\
$\quad$ Female & $3(5,8 \%)$ \\
Male & $40,7 \pm 6,9$ \\
Age & $18(32,2 \%)$ \\
Marital status & $25(48,01 \%)$ \\
$\quad$ Single & $8(15,6 \%)$ \\
Married & \\
Divorced & 0 \\
Education level & $1(1,9 \%)$ \\
Unlettered & $5(9,8 \%)$ \\
Incomplete elementary school & $9(17,6 \%)$ \\
Complete primary education & $25(49 \%)$ \\
Incomplete high school & $4(7,8 \%)$ \\
Complete high school & $2(3,9 \%)$ \\
Technical education & $5(9,8 \%)$ \\
Incomplete higher education & \\
Complete higher education & 0 \\
Number of brushes per day & 0 \\
None & $16(31,3 \%)$ \\
Once & $35(68,2 \%)$ \\
Twice & \\
Three times & $24(47 \%)$ \\
Flossing & $27(52,9 \%)$ \\
Use & \\
Don't use & $26(50,9 \%)$ \\
Mouthwash & $25(49 \%)$ \\
Use &
\end{tabular}

Source: Authors.

Table 3 shows the initial and final VPI and GBI values for caregivers of children and adolescents with CP. It can be seen that caregivers showed a significant reduction in VPI and GBI after oral health education $(\mathrm{P}<0.05)$.

Table 3. Visible Plaque Index and Gingival Bleeding Index values before and after guidance of caregivers of subjects with $\mathrm{CP}$

\begin{tabular}{llll}
\hline Variables & $\begin{array}{l}\text { Caregivers } \\
(\mathbf{n = 5 1})\end{array}$ & $\begin{array}{l}\text { Caregivers } \\
(\mathbf{n}=51)\end{array}$ & P Value \\
\hline & Before & After & \\
VPI & $42,4 \pm 18,7$ & $23,6 \pm 16,7$ & $0,0001^{*}$ \\
GBI & $23,5 \pm 21,2$ & $9,69 \pm 2,4$ & $0,0001^{*}$ \\
\hline
\end{tabular}

Abbreviations: VPI: Visible Plaque Index, GBI: Gingival Bleeding Index. Source: Authors.

\section{Discussion}

This study reflects the important role of dentists working with caregivers of children and adolescents with $\mathrm{CP}$, since there was a reduction in the values of visible plaque and gingival bleeding indices, with the application of the motivational method.

There are numerous difficulties faced by caregivers of children and adolescents with spastic CP in performing oral 
hygiene. These are related to increased masticatory muscle tone (M. T. B. R. Santos et al., 2017), the presence of biting and vomiting reflexes (Dos Santos \& Nogueira, 2005), restriction in mouth opening amplitude (M. T. B. R. Santos et al., 2017), feeding through a nasogastric tube, gastrostomy, (Cardona-Soria et al., 2020) and pasty diet due to the impairment of oral motricity (Rosenbaum et al., 2007). We must add the presence of malocclusions (Yogi, Alves, Guedes, \& Ciamponi, 2018) and the continuous use of medications, such as antiepileptics, which lead to a reduction in salivary flow, contributing to the development of oral diseases (Ferreira, Mayer, Kawamoto, \& Santos, 2019). Thus, maintaining oral health is a daily and extremely important challenge. Motivating the caregiver, as well as giving them tools to overcome the difficulties faced, resulted in the success observed in this study (Altun et al., 2010).

The best way to overcome the difficulties of lack of access to dental care for Special Needs Patients (SNP), is to make their caregivers aware of the impact that the benefits of oral health can have on their quality of life (DeMattei et al., 2012). However, it is necessary that the caregiver also know the importance of maintaining their own oral health (Grecu et al., 2019). Dentistry for SNP alerts caregivers and care providers about the importance of adopting measures to promote health, preventive and curative activities, with the interaction of patients with the professional and family being essential for the success of dental treatment (Grecu et al., 2019; Naseem et al., 2016). Dental appointments should start early, with periodic return according to the risk of the disease, making children and adolescents with disabilities familiar with the office environment, with the dental professional and with the dental treatment itself (Jan \& Jan, 2016).

In developed countries, there was a reduction in the prevalence of $\mathrm{CP}$, from 1.99 to 1.77 per 1,000 live births. In developing countries, such as Brazil, the estimated prevalence is much higher, increasing to 7 per thousand live births (Brasil, 2014; Sellier et al., 2016).

Regarding movement disorder, subjects with CP are classified into three types: spastic (characterized by increased muscle tone), dyskinetic (characterized by the presence of involuntary movement) and ataxic (due to changes in motor coordination and balance). The spastic type is the most prevalent, corresponding to approximately $70 \%$ of cases. The clinical patterns of the spastic type are hemiparesis, diparesis and tetraparesis (the most prevalent) (Sellier et al., 2016). The male subjects in this study were more numerous when compared to females, as reported in the literature (Romeo et al., 2016). This fact may be related to sexual dimorphism represented by a greater number of folds on the cortical surface for females. This genetic polymorphism predisposes men to develop spastic tetraparesis (Romeo et al., 2016).

Maternal respiratory and genitourinary infections emphasize the role of the maternal inflammatory environment in the pathogenesis of $\mathrm{CP}$ (Bear \& Wu, 2016). Premature births are related to the presence of high inflammatory levels in the umbilical cord, amniotic fluid and fetal blood, causing white matter damage and neurological disorders (CP), resulting in delayed neuropsychomotor development. Prematurity is related to severe inflammation (Carlo et al., 2011; Dammann \& O'Shea, 2008; Malaeb \& Dammann, 2009) and the presence of high levels of the cytokines TNF- $\alpha$, IFN-gamma, IL-1, IL-6 and IL-18, which are associated with lifelong repercussions. The presence of gingivitis in subjects with $\mathrm{CP}$ contributes to the imbalance of inflammatory cytokines, interfering with the response of the inflammatory process and the modulation of other immunological mechanisms (Kuban et al., 2017). A previous study by our research group performed mechanical periodontal treatment in subjects with CP and obtained a significant reduction in salivary levels of the cytokines TNF- $\alpha$, IL-1 $\beta$, IL-6 and IL-8 (Yoshida et al., 2019). Thus, it is necessary to act effectively in reducing the periodontal inflammatory process, since this condition is a risk for the development of other diseases such as diabetes mellitus, coronary heart disease and stroke (Beck, Moss, Morelli, \& Offenbacher, 2018).

Some medications used by children and adolescents with CP can reduce salivary flow and salivary protein production. These proteins are responsible for important functions, such as lubrication, antimicrobial action, enamel remineralization, buffer solution, and wound healing, among others. Changes in the production of these proteins can cause numerous problems, 
such as dryness of the oral mucosa, fungal infections (such as candidiasis), nonspecific gingivitis, dental erosion, enamel demineralization, increased plaque accumulation, difficulty chewing and swallowing, halitosis, among others (Plemons, AlHashimi, Marek, \& Affairs, 2014). The damage caused by the reduction in salivary flow can be minimized by offering a small amount of liquid throughout the day, using artificial saliva and also performing, as a preventive measure, the topical application of fluoride by the dentist (Plemons et al., 2014).

Some studies report that caregivers of children and adolescents with CP suffer from higher stress levels due to the high demand for daily activities, making them dedicate themselves almost exclusively to the patient's care (Kim \& Kim, 2019; Vadivelan, Sekar, Sruthi, \& Gopichandran, 2020). This stress worsens their quality of life and care, reflecting on their poor oral hygiene.

The caregivers in this study were instructed on the need to adopt preventive measures to control plaque and reduce the risk of the disease (Kallio, 2001). The resources used in performing oral hygiene, proposed in this study, greatly contributed to the reduction of plaque and gingival bleeding indices, demonstrating the effectiveness of the motivational method.

Thus, the expansion of the caregiver's knowledge in oral health and the mechanical and mechanical/chemical control program for bacterial plaque performed in this study, demonstrated the ability to improve the oral health of caregivers and of those in their care (Holtzman, Atchison, Macek, \& Markovic, 2017), in addition it made them multipliers of this practice (Shah et al., 2017), since after the guidelines and adaptations, a significant reduction in the VPI and GBI was observed, both in children and adolescents with CP, and their caregivers (Carlo et al., 2011).

There are still many challenges that need to be overcome when dealing with children and adolescents with CP in the dental office environment. These are related to fear of the unknown, changes in behavior related to communication difficulties, painful memories of previous treatments and instability in positioning in the dental chair, which could be minimized in routine dental care (Kallio, 2001).

The presence of the dentist in the multidisciplinary team dedicated to the prevention and maintenance of the quality of life related to the oral health of children and adolescents with CP is of fundamental importance (Tomita \& Fagote, 1999).

\section{Conclusion}

Oral hygiene instruction as a method of health promotion proved to be effective in controlling visible plaque and gingival bleeding for children and adolescents with cerebral palsy and their caregivers. Long-term studies are needed to assess caregivers' adherence to preventive practices and measures taken over time.

\section{References}

Aburahma, S. K., Mhanna, A., Al-Mousa, S., Al-Nusair, J., \& Al Habashneh, R. (2021). Dental health status and hygiene in children with cerebral palsy: A matched case-control study. Int J Paediatr Dent. doi:10.1111/ipd.12799

Altun, C., Guven, G., Akgun, O. M., Akkurt, M. D., Basak, F., \& Akbulut, E. (2010). Oral health status of disabled individuals attending special schools. Eur J Dent, 4(4), 361-366.

Bear, J. J., \& Wu, Y. W. (2016). Maternal Infections During Pregnancy and Cerebral Palsy in the Child. Pediatr Neurol, 57, 74-79. doi:10.1016/j.pediatrneurol.2015.12.018

Beck, J. D., Moss, K. L., Morelli, T., \& Offenbacher, S. (2018). Periodontal profile class is associated with prevalent diabetes, coronary heart disease, stroke, and systemic markers of C-reactive protein and interleukin-6. J Periodontol, 89(2), 157-165. doi:10.1002/JPER.17-0426

Brasil, M. d. S. (2014). Diretrizes de atenção à pessoa com paralisia cerebral. Retrieved from https://pesquisa.bvsalud.org/bvsms/resource/pt/mis-36838

Cardona-Soria, S., Cahuana-Cárdenas, A., Rivera-Baró, A., Miranda-Rius, J., Martín de Carpi, J., \& Brunet-Llobet, L. (2020). Oral health status in pediatric patients with cerebral palsy fed by oral versus enteral route. Spec Care Dentist, 40(1), 35-40. doi:10.1111/scd.12429

Cardoso, A. M., Gomes, L. N., Silva, C. R., Soares, R. e. S., Abreu, M. H., Padilha, W. W., \& Cavalcanti, A. L. (2014). Dental caries and periodontal disease in Brazilian children and adolescents with cerebral palsy. Int J Environ Res Public Health, 12(1), 335-353. doi:10.3390/ijerph120100335 
Carlo, W. A., McDonald, S. A., Tyson, J. E., Stoll, B. J., Ehrenkranz, R. A., Shankaran, S., . . Network, E. K. S. N. I. o. C. H. a. H. D. N. R. (2011). Cytokines and neurodevelopmental outcomes in extremely low birth weight infants. J Pediatr, 159(6), 919-925.e913. doi:10.1016/j.jpeds.2011.05.042

Chapple, I. L. C., Mealey, B. L., Van Dyke, T. E., Bartold, P. M., Dommisch, H., Eickholz, P., . . Yoshie, H. (2018). Periodontal health and gingival diseases and conditions on an intact and a reduced periodontium: Consensus report of workgroup 1 of the 2017 World Workshop on the Classification of Periodontal and Peri-Implant Diseases and Conditions. J Periodontol, 89 Suppl 1, S74-S84. doi:10.1002/JPER.17-0719

Chałas, R., Wójcik-Chęcińska, I., Woźniak, M. J., Grzonka, J., Święszkowski, W., \& Kurzydłowski, K. J. (2015). [Dental plaque as a biofilm - a risk in oral cavity and methods to prevent]. Postepy Hig Med Dosw (Online), 69, 1140-1148. doi:10.5604/17322693.1173925

Chi, D. L. (2018). Oral Health for US Children with Special Health Care Needs. Pediatr Clin North Am, 65(5), 981-993. doi:10.1016/j.pcl.2018.05.007

Dammann, O., \& O'Shea, T. M. (2008). Cytokines and perinatal brain damage. Clin Perinatol, 35(4), 643-663, v. doi:10.1016/j.clp.2008.07.011

DeMattei, R. R., Allen, J., \& Goss, B. (2012). A service-learning project to eliminate barriers to oral care for children with special health care needs. $J$ Sch Nurs, 28(3), 168-174. doi:10.1177/1059840511432473

Dos Santos, M. T., \& Nogueira, M. L. (2005). Infantile reflexes and their effects on dental caries and oral hygiene in cerebral palsy individuals. $J$ Oral Rehabil, 32(12), 880-885. doi:10.1111/j.1365-2842.2005.01518.x

DU, R. Y., McGrath, C., Yiu, C. K., \& King, N. M. (2010). Oral health in preschool children with cerebral palsy: a case-control community-based study. Int J Paediatr Dent, 20(5), 330-335. doi:10.1111/j.1365-263X.2010.01062.x

Ferreira, A. C. F. M., Mayer, M. P. A., Kawamoto, D., \& Santos, M. T. B. R. (2019). Constipation, antiepileptic drugs, and gingivitis in children and adolescents with cerebral palsy. Int J Paediatr Dent, 29(5), 635-641. doi:10.1111/ipd.12488

Grecu, A. G., Balazsi, R., Dudea, D., Mesaroş, A., Strîmbu, M., \& Dumitraşcu, D. L. (2019). Oral health related quality of life and self-esteem in a general population. Med Pharm Rep, 92(Suppl No 3), S65-S72. doi:10.15386/mpr-1520

Highfield, J. (2009). Diagnosis and classification of periodontal disease. Aust Dent J, 54 Suppl 1, S11-26. doi:10.1111/j.1834-7819.2009.01140.x

Holtzman, J. S., Atchison, K. A., Macek, M. D., \& Markovic, D. (2017). Oral Health Literacy and Measures of Periodontal Disease. J Periodontol, 88(1), 7888. doi:10.1902/jop.2016.160203

Jan, B. M., \& Jan, M. M. (2016). Dental health of children with cerebral palsy. Neurosciences (Riyadh), 21(4), 314-318. doi:10.17712/nsj.2016.4.20150729

Kallio, P. J. (2001). Health promotion and behavioral approaches in the prevention of periodontal disease in children and adolescents. Periodontol 2000, 26, 135-145. doi:10.1034/j.1600-0757.2001.2260107.x

Kim, D. J., \& Kim, Y. J. (2019). Effects of the Parenting Efficacy Improvement Program for mothers as primary caregivers of children with cerebral palsy under rehabilitation. J Exerc Rehabil, 15(6), 763-768. doi:10.12965/jer.1938654.327

Koman, L. A., Smith, B. P., \& Shilt, J. S. (2004). Cerebral palsy. Lancet, 363(9421), 1619-1631. doi:10.1016/S0140-6736(04)16207-7

Kuban, K. C., Joseph, R. M., O'Shea, T. M., Heeren, T., Fichorova, R. N., Douglass, L., Investigators, E. L. G. A. N. E. S. (2017). Circulating InflammatoryAssociated Proteins in the First Month of Life and Cognitive Impairment at Age 10 Years in Children Born Extremely Preterm. J Pediatr, 180, 116-123.e111. doi:10.1016/j.jpeds.2016.09.054

Kumar, P. S., Griffen, A. L., Barton, J. A., Paster, B. J., Moeschberger, M. L., \& Leys, E. J. (2003). New bacterial species associated with chronic periodontitis. J Dent Res, 82(5), 338-344. doi:10.1177/154405910308200503

Longo, M., \& Hankins, G. D. (2009). Defining cerebral palsy: pathogenesis, pathophysiology and new intervention. Minerva Ginecol, 61(5), 421-429.

Malaeb, S., \& Dammann, O. (2009). Fetal inflammatory response and brain injury in the preterm newborn. J Child Neurol, 24(9), 1119-1126. doi: $10.1177 / 0883073809338066$

Naseem, M., Shah, A. H., Khiyani, M. F., Khurshid, Z., Zafar, M. S., Gulzar, S., . . Khalil, H. S. (2016). Access to oral health care services among adults with learning disabilities: a scoping review. Ann Stomatol (Roma), 7(3), 52-59. doi:10.11138/ads/2016.7.3.052

O'Leary, T. J., Drake, R. B., \& Naylor, J. E. (1972). The plaque control record. J Periodontol, 43(1), 38. doi:10.1902/jop.1972.43.1.38

Oskoui, M., Coutinho, F., Dykeman, J., Jetté, N., \& Pringsheim, T. (2013). An update on the prevalence of cerebral palsy: a systematic review and metaanalysis. Dev Med Child Neurol, 55(6), 509-519. doi:10.1111/dmcn.12080

Petersen, P. E. (2003). The World Oral Health Report 2003: continuous improvement of oral health in the 21st century--the approach of the WHO Global Oral Health Programme. Community Dent Oral Epidemiol, 31 Suppl 1, 3-23. doi:10.1046/j..2003.com122.x

Pini, D. M., Fröhlich, P. C., \& Rigo, L. (2016). Oral health evaluation in special needs individuals. Einstein (Sao Paulo), 14(4), 501-507. doi:10.1590/S167945082016AO3712

Plemons, J. M., Al-Hashimi, I., Marek, C. L., \& Affairs, A. D. A. C. o. S. (2014). Managing xerostomia and salivary gland hypofunction: executive summary of a report from the American Dental Association Council on Scientific Affairs. J Am Dent Assoc, 145(8), 867-873. doi:10.14219/jada.2014.44

Rodrigues dos Santos, M. T., Masiero, D., Novo, N. F., \& Simionato, M. R. (2003). Oral conditions in children with cerebral palsy. J Dent Child (Chic), 70(1), 40-46. 
Research, Society and Development, v. 10, n. 15, e205101522571, 2021

(CC BY 4.0) | ISSN 2525-3409 | DOI: http://dx.doi.org/10.33448/rsd-v10i15.22571

Romeo, D. M., Sini, F., Brogna, C., Albamonte, E., Ricci, D., \& Mercuri, E. (2016). Sex differences in cerebral palsy on neuromotor outcome: a critical review. Dev Med Child Neurol, 58(8), 809-813. doi:10.1111/dmcn.13137

Rosenbaum, P., Paneth, N., Leviton, A., Goldstein, M., Bax, M., Damiano, D., Jacobsson, B. (2007). A report: the definition and classification of cerebral palsy April 2006. Dev Med Child Neurol Suppl, 109, 8-14.

Santos, M. T., Ferreira, M. C., Mendes, F. M., \& de Oliveira Guaré, R. (2014). Assessing salivary osmolality as a caries risk indicator in cerebral palsy children. Int J Paediatr Dent, 24(2), 84-89. doi:10.1111/ipd.12030

Santos, M. T. B. R., Nascimento, K. S., Carazzato, S., Barros, A. O., Mendes, F. M., \& Diniz, M. B. (2017). Efficacy of photobiomodulation therapy on masseter thickness and oral health-related quality of life in children with spastic cerebral palsy. Lasers Med Sci, 32(6), 1279-1288. doi:10.1007/s10103-0172236-4

Sellier, E., Platt, M. J., Andersen, G. L., Krägeloh-Mann, I., De La Cruz, J., Cans, C., \& Network, S. o. C. P. (2016). Decreasing prevalence in cerebral palsy: a multi-site European population-based study, 1980 to 2003. Dev Med Child Neurol, 58(1), 85-92. doi:10.1111/dmcn.12865

Shah, A. H., Naseem, M., Khan, M. S., Asiri, F. Y. I., AlQarni, I., Gulzar, S., \& Nagarajappa, R. (2017). Oral health knowledge and attitude among caregivers of special needs patients at a Comprehensive Rehabilitation Centre: an analytical study. Ann Stomatol (Roma), 8(3), 110-116. doi:10.11138/ads/2017.8.3.110

Tomita, N. E., \& Fagote, B. F. (1999). Programa educativo em saúde bucal para pacientes especiais. In Odontologia e Sociedade (Vol. v. 1, pp. p. 45-50 ）. São Paulo: USP-FOB.

Vadivelan, K., Sekar, P., Sruthi, S. S., \& Gopichandran, V. (2020). Burden of caregivers of children with cerebral palsy: an intersectional analysis of gender, poverty, stigma, and public policy. BMC Public Health, 20(1), 645. doi:10.1186/s12889-020-08808-0

Vitrikas, K., Dalton, H., \& Breish, D. (2020). Cerebral Palsy: An Overview. Am Fam Physician, 101(4), 213-220.

Yogi, H., Alves, L. A. C., Guedes, R., \& Ciamponi, A. L. (2018). Determinant factors of malocclusion in children and adolescents with cerebral palsy. Am J Orthod Dentofacial Orthop, 154(3), 405-411. doi:10.1016/j.ajodo.2017.11.042

Yoshida, R. A., Gorjão, R., Mayer, M. P. A., Corazza, P. F. L., Guare, R. O., Ferreira, A. C. F. M., \& Santos, M. T. B. R. (2019). Inflammatory markers in the saliva of cerebral palsy individuals with gingivitis after periodontal treatment. Braz Oral Res, 33, e033. doi:10.1590/1807-3107bor-2019.vol33.0033 